Pachnik K., Charakter odpowiedzialności naruszyciela za stosowanie nieucziwych praktyk rynkowych, „Ekonomia i Prawo”, Polszakiewicz B., Boehlke J. (red.), Tom XII, nr 2/2013, ss. 261-272. DOI: http://dx.doi.org/10.12775/EiP.2013.020

\author{
KAROL PACHNIK
}

\title{
CHARAKTER ODPOWIEDZIALNOŚCI NARUSZYCIELA ZA STOSOWANIE NIEUCZCIWYCH PRAKTYK RYNKOWYCH ${ }^{\diamond}$
}

\section{STRESZCZENIE}

Przeciwdziałanie nieuczciwym praktykom rynkowym jest konstytucyjnym obowiązkiem ciążącym na władzy publicznej (władzach publicznych). Ustawodawca wprowadził cywilnoprawne i karnoprawne środki ochronne. Krąg podmiotów mogących skorzystać z ochrony cywilnoprawnej wydaje się nadmiernie ograniczony, natomiast regulacja karnoprawna nie jest pozbawiona luk. Być może uzasadnione jest rozpoczęcie dyskusji nad ewentualną nowelizacją ustawy.

Słowa kluczowe: nieuczciwa konkurencja, nieuczciwe praktyki rynkowe. ochrona konkurencji Klasyfikacja JEL: K22, K23

\section{THE IMPORTANCE OF RESPONSIBILITY FOR USING FRAUDULENT MARKET'S ACTIONS}

\section{SUMMARY}

By virtue of article 76 of Constitution and The act about prevention of fraudulent market's actions, domestic bodies are obligated to protect consumers against trader's

* Karol Pachnik, Uniwersytet Przyrodniczo-Humanistyczny w Siedlcach, Wydział Nauk Ekonomicznych i Prawnych, Instytut Administracji, Samorządu i Prawa, tel.: +48 2564315 01, e-mail: k.pachnik@uph.edu.pl.

$\diamond$ Publikacja dofinansowana ze środków Rektora Uniwersytetu Przyrodniczo-Humanistycznego w Siedlcach przeznaczonych na badania służące rozwojowi młodych naukowców. 
actions with are unlawful. This article presents scope of Polish act about prevention of fraudulent market's actions. Shows definition of fraudulent market's actions, types of that actions and recipients of that act. Author presents also scope of consumer's protection, domestic bodies, with are deal that and specific conditions of proceeding in violation that act. Responsibility for using fraudulent market's actions in Polish law very often lead to criminal responsibility but that process is not enough definite. This article maybe will be beginning of discussion about changes in the act about prevention of fraudulent market's actions.

Keywords: unfair competition, unfair market practices, protection of competition JEL Classification: K22, K23

\section{WSTĘP}

Ustawa o zwalczaniu nieuczciwej konkurencji ${ }^{3}$ w ciągu 20 lat obowiązywania stałą się przedmiotem pewnego zainteresowania w piśmiennictwie prawniczym.

Dotychczas przedstawiciele nauki prawa w dużo mniejszym zakresie eksploatowali pola badawcze dotyczące ustawy o przeciwdziałaniu nieuczciwym praktykom rynkowym ${ }^{4}$. Stąd też warto podjąć rozważania teoretyczne zmierzające do scharakteryzowania instytucji prawnych istniejących od dwóch dekad w krajowym porządku prawnym.

\section{UWAGI WPROWADZAJĄCE}

Stanowiąca główne pole odniesienia dla dalszych rozważań wymieniona wyżej ustawa o przeciwdziałaniu nieuczciwym praktykom rynkowym, co zrozumiałe różni się zakresem regulacji od innych aktów prawnych regulujących materię ochrony konkurencji i konsumentów ${ }^{5}$.

${ }^{3}$ Ustawa o zwalczaniu nieuczciwej konkurencji z dnia 16 kwietnia 1993 r., Dz. U. Nr 47, poz. 211 ze $\mathrm{zm}$.

${ }^{4}$ Ustawa o przeciwdziataniu nieuczciwym praktykom rynkowym z dnia 23 sierpnia 2007 r., Dz. U. Nr 171, poz. 1206.

${ }_{5}$ Przede wszystkim - poza wymienionymi aktami prawnymi - do omawianego zakresu regulacji zaliczyć można:

- Ustawe o ochronie konkurencji i konsumentów z dnia 16 lutego 2007 r., Dz. U. Nr 50, poz. 331 ze zm.;

- Ustawe o Inspekcji Handlowej z dnia 15 grudnia 2000 r., Dz. U. 2001, Nr 4, poz. 25 ze zm.;

- Ustawe o ogólnym bezpieczeństwie produktów z dnia 12 grudnia 2003 r., Dz. U. Nr 229, poz. 2275 ze zm.; 
Zakres przedmiotowy ustawy zakreślony został w jej art. 1 (ustawa określa nieuczciwe praktyki rynkowe w działalności gospodarczej i zawodowej oraz zasady przeciwdziałania tym praktykom w interesie konsumentów i w interesie publicznym).

Ochrona przed nieuczciwymi praktykami rynkowymi jest konstytucyjnym obowiązkiem nałożonym na władze publiczne z mocy art. 76 Konstytucji RP (częśc: Wolności i prawa ekonomiczne, socjalne i kulturalne). Przedmiotowa ustawa ma charakter doprecyzowujący co do zakresu ochrony wobec regulacji zapisanych w Ustawie Zasadniczej. Dodatkowo jej wprowadzenie podyktowane zostało koniecznością implementacji do krajowego porządku prawnego dyrektywy 2005/29/WE Parlamentu Europejskiego i Rady z 11.05.2005 r. dotyczącej nieuczciwych praktyk handlowych stosowanych przez przedsiębiorstwa wobec konsumentów na rynku wewnętrznym oraz zmieniająca dyrektywę Rady 84/450/EWG, dyrektywy 97/7/WE, 98/27/WE i 2002/65/WE Parlamentu Europejskiego i Rady oraz rozporządzenie (WE) nr 2006/2004 Parlamentu Europejskiego i Rady. Analiza tekstu ustawy o przeciwdziałaniu nieuczciwym praktykom rynkowym i porównanie $z$ dyrektywą o nieuczciwych praktykach handlowych prowadzi do wniosku, że ustawa o przeciwdziałaniu nieuczciwym praktykom rynkowym jest po prostu tłumaczeniem dyrektywy ${ }^{6}$.

Sama ustawa to tylko 21 artykułów umieszczonych w 5 rozdziałach (Rozdział 1. Przepisy ogólne, Rozdział 2. Nieuczciwe praktyki rynkowe, Rozdział 3. Odpowiedzialność cywilna, Rozdział 4. Przepisy karne, Rozdział 5. Zmiany w przepisach obowiązujących, przepis przejściowy i końcowy).

Ustawodawca określił zdecydowanie węższy zakres ochrony (a tym samym węższy katalog zakazanych działań i przysługujących środków ochronnych) w porównaniu do ustawy o zwalczaniu nieuczciwej konkurencji.

\subsection{NIEUCZCIWE PRAKTYKI RYNKOWE}

Całość regulacji ustawowych sprowadza się do zakazania (i wprowadzenia środków ochronnych) nieuczciwych praktyk rynkowych, którymi są działania stosowane przez przedsiębiorców wobec konsumentów, o ile są sprzeczne

- Ustawę o szczególnych warunkach sprzedaży konsumenckiej oraz o zmianie Kodeksu cywilnego z dnia 27 lipca 2002 r., Dz. U. Nr 141, poz. 1176 ze zm.;

- Ustawe o ochronie niektórych praw konsumentów oraz o odpowiedzialności za szkode wyrzadzona przez produkt niebezpieczny z dnia 2 marca 2000 r., Dz. U. Nr 22, poz. 271.

${ }^{6}$ D. du Cane, Nieucziwa konkurencja a dobre obyczaje oraz class action po polsku, „Przegląd Prawa Handlowego", 2009, nr 3. s. 53. 
z dobrymi obyczajami i w istotny sposób zniekształca lub może zniekształcić zachowanie rynkowe przeciętnego konsumenta przed zawarciem umowy dotyczącej produktu, w trakcie jej zawierania lub po jej zawarciu ${ }^{7}$. Do uznania danej praktyki za naruszającą zbiorowe interesy konsumentów wystarczy potencjalne zagrożenie naruszenia interesów konsumentów. Niezasadne jest uzależnienie wydania decyzji (za każdym razem zagrożenia stosowaniem praktyki) od badania opinii publicznej czy, w odczuciu badanych, dana informacja mogła ich wprowadzić w błąd8.

$\mathrm{Na}$ uwagę zasługuje posłużenie się terminem „dobre obyczaje”. Pojęcie to nie ma swojej definicji legalnej w prawie krajowym, nie jest też tożsame rozpowszechnionemu w prawie polskim pojęciu „zasad współżycia społecznego”. W orzecznictwie oceniono, że istotą pojęcia dobrego obyczaju jest szeroko pojęty szacunek dla drugiego człowieka. W stosunkach z konsumentami powinien on wyrażać się właściwym informowaniem o przysługujących uprawnieniach, niewykorzystywaniu uprzywilejowanej pozycji profesjonalisty i rzetelnym traktowaniu partnerów umów. Za sprzeczne $\mathrm{z}$ dobrymi obyczajami można uznać działania zmierzające do niedoinformowania, dezorientacji, wywołania błędnego przekonania u konsumenta, a także wykorzystania jego niewiedzy i naiwności9.

Zauważyć trzeba, że ustawodawca określił zakres ustawy w sposób węższy, niż wynikałoby to z unormowań konstytucyjnych. Samo zrównanie nieuczciwych praktyk rynkowych $\mathrm{z}$ zachowaniami stosowanymi wobec konsumentów prowadzi do niesankcjonowania określonych typów uczynków nacechowanych nieuczciwością, ale nieskierowanych do konsumentów. Wobec takiej regulacji jeden czyn może stanowić zakazaną praktykę rynkową zakresowo w zależności od odbiorcy nieuczciwego zachowania (podanie nierzetelnej informacji odbierane przez konsumenta będzie zakazaną praktyką rynkową, a ta sama nierzetelna informacja odebrana przez przedsiębiorcę nie będzie miała takiego waloru).

Rozróżnienie takie będzie prowadziło do zróżnicowania możliwości przeciwdziałania czynowi, pozostawiając określone podmioty bez ochrony przewidzianej w omawianej ustawie. Być może ustawodawca stanął na stanowisku, że prawo antymonopolowe nie wkracza w stosunki kontraktowe pomiędzy przedsiębiorcami, dopóki brakuje dowodów na to, że sytuacja taka powoduje

7 Ustawa o przeciwdziataniu nieuczciwym praktykom rynkowym..., op. cit., art. 4 ust. 1.

${ }^{8}$ Wyrok Saqu Ochrony Konkurencji i Konsumentów z dnia 25 marca 2010 r. XVII Ama 43/2009 Dz. Urz. UOKiK. 2010.3.19.

9 Wyrok Sądu Ocbrony Konkurencji i Konsumentów z dnia 23 lutego 2006 r., XVII Ama 118/04, opubl. Lex. 
sprzeczne $z$ interesem publicznym antykonkurencyjne skutki na danym rynku, w tym szkody dla konsumentów ${ }^{10}$.

Co do zasady nieuczciwe praktyki rynkowe to działanie naruszyciela polegające na wprowadzaniu w błąd (np. rozpowszechnianiu nieprawdziwych informacji), zaniechaniu działania (np. nieprzekazywaniu określonych informacji) lub na wywieraniu niedozwolonego nacisku ${ }^{11}$ (np. wywoływanie przeświadczenie, że nienabycie produktu może grozić utratą pracy lub środków do życia). Warte odnotowania jest, że aktualnie ${ }^{12}$ to właśnie zapisy omawianej ustawy stanowią o zakazie organizowania sprzedaży w systemie konsorcyjnym $^{13}$, a treść uregulowania jest zbliżona do wcześniej obowiązujących zapisów ustawy o zwalczaniu nieuczciwej konkurencji.

Sprawcą nieuczciwej praktyki rynkowej jest w każdym przypadku przedsiębiorca, a adresatem takich zachowań profesjonalisty jest konsument ${ }^{14}$. Katalog czynów mieszczący się w pojęciu nieuczciwych praktyk rynkowych nie jest zamknięty ${ }^{15}$. Każde zachowanie spełniające kryteria zastrzeżone w art. 4 . ust. 1 komentowanej ustaw może zostać potraktowane jako czyn nieuczciwej konkurencji. Powyższe spostrzeżenie nie jest kontrowersyjne, zasadza się na analizie treści art. 4 ust. 2 omawianej ustawy - na użyciu zwrotu „w szczególności” w odniesieniu do stypizowania charakteru nieuczciwych praktyk rynkowych.

\section{ZAKRES OCHRONY}

Ustawodawca nie wprowadził instrumentów ochrony publicznoprawnej, koncentrując się na uregulowaniu autonomicznych zasad odpowiedzialności cywilnej oraz na wprowadzeniu tzw. pozakodeksowych przepisów karnych, w odniesieniu do których odpowiednie zastosowanie znajdują przepisy części ogólnej kodeksu karnego (przestępstwa) oraz części ogólnej kodeksu wy-

${ }^{10}$ C. Banasiński i M. Bychowska, Ekonomiczne aspekty stosowania art. 15 ust. 1 pkt 4 ustawy o zwalczaniu nieuczciwej konkurencji, „Przegląd Prawa Handlowego”, 2011, nr 11. s. 4.

${ }_{11}$ Tzw. agresywne praktyki rynkowe.

12 A. Michalak, Przeciwdziatanie nieuczciwym praktykom rynkowym. Komentarz (pkt 11 komentarza do art. 2) C.H. Beck, Warszawa 2008, Legalis.

13 por. Ustawa o przeciwdziataniu nieuczciwym praktykom rynkowym..., op. cit., art. 16, ust. 1.

${ }^{14}$ K. Kopaczyńska-Pietrzak, Czyn nieuczciwej konkurencji a nieuczciwa praktyka rynkowa, „Monitor Prawa Handlowego”, 2012, nr 3.s. 30.

15 A. Michalak, Przeciwdziatanie nieucziwym praktykom rynkowym. Komentarz..., op. cit., pkt 10 komentarza do art. 4. 
kroczeń $^{16}$ (wykroczenia) ${ }^{17}$; przy czym w kreacji środków ochronnych ustawodawca miał pełną swobodę ${ }^{18}$.

Tym samym Prezes Urzędu Ochrony Konkurencji i Konsumentów (UOKiK) nie ma kognicji do przeciwdziałania aktami administracyjnymi zachowaniom będącym nieuczciwym praktykom rynkowym.

Prezes UOKiK nie ma również legitymacji procesowej czynnej w sprawach cywilnych dotyczących dokonania nieuczciwej praktyki rynkowej.

\subsection{ODPOWIEDZIALNOŚĆ CYWILNA}

Sama regulacja odpowiedzialności cywilnej (art. 12-14 ustawy o przeciwdziałaniu nieuczciwym praktykom rynkowym) mimo niezbyt rozbudowanej treści wprowadza regulacje warte odnotowania.

Zakres środków ochronnych ${ }^{19}$ zawiera $\mathrm{w}$ sobie treści zbieżne $\mathrm{z}$ katalogiem środków ochrony przysługujących w przypadku naruszenia dóbr osobistych ${ }^{20}$ z tym rozszerzeniem, że możliwe jest także żądanie naprawienia szkody na zasadach ogólnych ${ }^{21}$. Ustalone w ustawie reguły odpowiedzialności cywilnej spełniają zarówno funkcje kompensacyjne, jak i represyjne (zasądzenie odpowiedniej kwoty pieniężnej na określony cel społeczny).

16 Ustawa z 20.05.1971 r. - Kodeks wykroczeń, tekst jedn.: Dz. U. z 2010 r. Nr 46, poz. 275.

$17 \mathrm{~J}$. Raglewski, Wybrane problemy interpretacyjne przepisów karnych ustawy o zwalczaniu nieuczciwej konkurencji z 1993 r., „Zeszyty Naukowe Uniwersytetu Jagiellońskiego. Prace z Prawa Własności Intelektualnej”, 2010, t. 109, nr 3. s. 124.

18 A. Szwaja, Janusz, Tischner, Implementacja dyrektywy 2005/29/WE o zwalczaniu nieuczciwych praktyk handlowych do prawa polskiego, „Monitor Prawniczy”, 2007, nr 20, s. 1120.

${ }_{19}$ Art. 12. 1. W razie dokonania nieuczciwej praktyki rynkowej konsument, którego interes został zagrożony lub naruszony, może żądać: 1) zaniechania tej praktyki; 2) usunięcia skutków tej praktyki; 3) złożenia jednokrotnego lub wielokrotnego oświadczenia odpowiedniej treści i w odpowiedniej formie; 4) naprawienia wyrządzonej szkody na zasadach ogólnych, w szczególności żądania unieważnienia umowy z obowiązkiem wzajemnego zwrotu świadczeń oraz zwrotu przez przedsiębiorcę kosztów związanych z nabyciem produktu; 5) zasądzenia odpowiedniej sumy pieniężnej na określony cel społeczny związany ze wspieraniem kultury polskiej, ochroną dziedzictwa narodowego lub ochroną konsumentów.

${ }^{20}$ Por. Ustawa z dnia 23 kwietnia 1964 r. Kodeks cywilny, op. cit., Dz. U. Nr 16, poz. 93 ze zm., art. 24.

${ }^{21} \mathrm{~W}$ nauce prawa podaje się, że $\mathrm{w}$ istocie uprawnienie to zawiera $\mathrm{w}$ sobie roszczenie odszkodowawcze i uprawnienie do żądania unieważnienia umowy (M. Grochowski, Wadliwość umów konsumenckich (w świetle przepisów o nieucziwych praktykach rynkowych), „Państwo i Prawo”, 2009, nr 7. s. 59). Pogląd ten nie wydaje się być zupełny bowiem art. 12, ust. 1 pkt 3 ustawy o przeciwdziałaniu nieuczciwym praktykom rynkowym nie zawiera zamkniętego katalogu roszczeń. 
Co istotne, wskazane roszczenia przysługują wyłącznie konsumentowi, czyli osobie zdefiniowanej $\mathrm{w}$ art. $22^{1}$ Kodeksu cywilnego ${ }^{22}$; o ile jego interes został narażony lub zagrożony - $\mathrm{w}$ trybie skargi indywidualnej ${ }^{23}$ tzw. actio popularis $^{24}$ czy "class action ${ }^{25 ”}$.

Sam konsument $\mathrm{z}$ zasady uważany jest za podmiot słabszy - nieprofesjonalistę w obrocie prawnym. Stąd 4 kategorie podmiotów zyskały uprawnienia do występowania $\mathrm{z}$ roszczeniami $\mathrm{w}$ imieniu konsumenta (podmioty uprawnione). Są to 1) Rzecznik Praw Obywatelskich; 2) Rzecznik Ubezpieczonych; 3) krajowa lub regionalna organizacja, której celem statutowym jest ochrona interesów konsumentów; 4) powiatowy (miejski) rzecznik konsumentów. Jednocześnie nie jest możliwe, aby podmioty te występowały w imieniu konsumenta $\mathrm{z}$ roszczeniami odszkodowawczymi.

Jednocześnie w ustawie dokonano dwóch istotnych pominięć. Mianowicie nie zapewniono możliwość ochrony interesów konsumentów Prezesowi UOKiK. Organ ten nie posiada ani środków administracyjnoprawnych, ani kompetencji do ochrony naruszonego interesu konsumentów w odniesieniu do nieuczciwych praktyk rynkowych.

Podobnie ustawodawca nie przewidział mechanizmów ochrony rynku przez innych przedsiębiorców. Nie mogą oni występować z powództwem cywilnym i żądać zastosowania środków przewidzianych w art. 12 omawianej ustawy, nawet o ile nieuczciwa praktyka rynkowa godzi nie tylko $\mathrm{w}$ interes konsumentów, ale i interes określonego przedsiębiorcy, np. w skutek zastosowania nierzetelnej reklamy porównawczej ${ }^{26}$ czy bezprawnego użycia znaku towarowego w meta-tags ${ }^{27}$.

Ustawodawca przełamał ogólną zasadę ciężaru dowodu zawartą w art. 6 Kodeksu cywilnego ${ }^{28}$ poprzez unormowanie, że ciężar dowodu na okoliczność tego, że dana praktyka rynkowa nie stanowi nieuczciwej praktyki wprowadza-

22 Za konsumenta uważa się osobę fizyczną dokonującą czynności prawnej niezwiązanej bezpośrednio z jej działalnością gospodarczą lub zawodową.

${ }_{23}$ M. Namysłowska, Nowa ustawa o przeciwdziataniu nieuczciwym praktykom rynkowym, „Monitor Prawniczy", 2007, nr 23, s. 1291.

${ }^{24}$ W. Jurasz, Zakres podmiotowy regulacji ustaw: o ochronie konkurencji i konsumentów, zwalczaniu nieuczciwej konkurencji oraz przeciwdziataniu nieuczciwym praktykom rynkowym. Konsument jako podmiot chroniony przed praktykami zakazanymi w tych ustawach, „Ochrona konkurencji i konsumentów w Polsce - wybrane zagadnienia Dodatek do Monitora Prawniczego 2010 nr 8", s. 12.

${ }_{25}$ D. du Cane, Nieuczciwa konkurencja a dobre obyczaje oraz class action po polsku..., op. cit., s. 58.

${ }^{26}$ Por. art. 5 ust. 2 pkt 4 omawianej ustawy.

27 Por. M. Sieradzka, Naruszenie prawa do znaku towarowego użytego w meta-tags, „Monitor Prawniczy", 2008, nr 12.

${ }^{28}$ Ciężar udowodnienia faktu spoczywa na osobie, która $\mathrm{z}$ faktu tego wywodzi skutki prawne. 
jącej w błąd, spoczywa na przedsiębiorcy, któremu zarzuca się stosowanie nieuczciwej praktyki rynkowej. W doktrynie pojawiła się ocena, że dla przedsiębiorców (będących przecież profesjonalistami) nie stanowi żadnej trudności przedstawienie dowodu (odpowiednich informacji oraz dokumentacji), dzięki któremu możliwa stanie się ocena danej praktyki pod kątem wprowadzenia konsumentów w błąd albo nie ${ }^{29}$.

Dodatkowo wprowadzono 3-letni termin przedawnienia roszczeń z tytutu nieuczciwej praktyki rynkowej (z wyjątkiem roszczenia odszkodowawczego), nie precyzując jednocześnie, czy bieg terminu liczy się od dnia dokonania nieuczciwej praktyki rynkowej, od dnia, kiedy wywołała ona skutek, czy od dnia, kiedy o tejże praktyce dowiedział się konsument ${ }^{30}$.

\subsection{ODPOWIEDZIALNOŚĆ KARNA}

Zakres odpowiedzialności karnej nie jest nadmiernie rozbudowany. Jednocześnie z powodu niekonsekwencji ustawodawcy warto bliżej opisać zastany stan prawny.

Podstawowym założeniem ustawodawcy jest penalizacja zachowań stanowiących agresywną praktykę rynkową. Ustalono, że czyny takie stanowią wykroczenia, a przewidzianą karą jest grzywna. Ponieważ katalog agresywnych praktyk rynkowych nie jest katalogiem zamkniętym, podstawowe uregulowanie odpowiedzialności karnej w ustawie o przeciwdziałaniu nieuczciwym praktykom rynkowym spotyka się $\mathrm{w}$ doktrynie prawa $\mathrm{z}$ krytyką, ze względu na swoją nieokreśloność ${ }^{31}$.

Kodeks postępowania w sprawach o wykroczenia ${ }^{32}$ (k.p.w.w.) zawiera szerszy katalog podmiotów mogących pełnić rolę oskarżycieli niż analogiczna regulacja Kodeksu postępowania karnego ${ }^{33}$. Z mocy art. 17 §3 zapisów k.p.w.w. organom administracji, organom kontroli państwowej przysługują uprawnienia oskarżyciela publicznego wówczas, gdy w zakresie swego działania w tym w trakcie prowadzonych czynności wyjaśniających, ujawniły wykroczenia i wy-

${ }^{29}$ M. Sieradzka, Actio popularis jako instrument ochrony interesów konsumentów przed nieuczciwymi praktykami rynkowymi, „Przegląd Prawa Handlowego”, 2008, nr 3. s. 44.

${ }_{30}$ Podobnie R. Stefanicki, Ustawa o przeciwdziataniu nieucziwym praktykom rynkowym. Komentarz (do rozdziału 3, art. 14), LexisNexis, Warszawa 2009, LexPolonica.

31 A. Zientara, Ostatnie zmiany ustawy o zwalczaniu nieuczciwej konkurencji, „Monitor Prawniczy”, 2001, nr 6. s. 296.

${ }^{32}$ Ustawa z dnia 24 sierpnia 2001 r. Kodeks postepowania w sprawach o wykroczenia, Dz. U. $\mathrm{Nr} 106$, poz. 1148, ze zm.

${ }^{33}$ Ustawa z dnia 6 czerwca 1997 r. Kodeks postępowania karnego, Dz. U. Nr 89, poz. 555 ze zm. 
stąpiły z wnioskiem o ukaranie. Regulacja taka nie wyklucza możliwości występowania $\mathrm{z}$ wnioskami o ukaranie przez Prezesa UOKiK.

Wystąpienie $z$ wnioskiem o ukaranie na podstawie ustawy o przeciwdziałaniu nieuczciwym praktykom rynkowym ograniczone jest dodatkowo wyłącznie do przypadków zażądania ścigania wykroczenia sformułowanych przez pokrzywdzonego (przeciętnego konsumenta ${ }^{34}$ ) lub opisane wyżej podmioty uprawnione. W praktyce więc Prezes UOKIK nie nabył uprawnień do ścigania $\mathrm{w}$ trybie postępowania $\mathrm{w}$ sprawach o wykroczenia zachowań stanowiących nieuczciwe praktyki rynkowe.

\subsection{KARALNOŚĆ SYSTEMU KONSORCYJNEGO}

Bardziej szczegółowe regulacje zawarto w odniesieniu do penalizacji prowadzenia działalności w formie systemu konsorcyjnego - przez co rozumie się prowadzenie działalności gospodarczej polegającej na zarządzaniu mieniem gromadzonym $\mathrm{w}$ ramach grupy $\mathrm{z}$ udziałem konsumentów, utworzonej w celu sfinansowania zakupu produktu na rzecz uczestników grupy ${ }^{35}$.

Regulacja ta nie jest najtrafniejsza ze względu na swój ograniczony zakres. Ustawa nie zawiera odrębnej definicji działalności gospodarczej, stąd odnosić się należy do definicji zawartej w ustawie o swobodzie działalności gospodarczej $^{36}$ (s.d.g.). Co do zasady, działalnością gospodarczą w myśl zapisów s.d.g jest zarobkowa działalność wytwórcza, budowlana, handlowa, usługowa oraz poszukiwanie, rozpoznawanie i wydobywanie kopalin ze złóż, a także działalność zawodowa, wykonywana w sposób zorganizowany i ciągły ${ }^{37}$. Przez takie uregulowanie nie każda działalność polegająca na zarządzaniu mieniem gromadzonym $w$ ramach grupy $\mathrm{z}$ udziałem konsumentów $\mathrm{w}$ celu finansowania zakupu produktu $\mathrm{w}$ systemie konsorcyjnym czy organizowaniu grupy konsumentów-uczestników systemu konsorcyjnego, będzie podlegała karze. Przykładowo, jak oceniono w orzecznictwie sądów administracyjnych niezarobkowy charakter działalności kas oszczędnościowo-kredytowych przesądza o tym, że działalność kas oszczędnościowo-kredytowych nie może być uznana za działalność gospodarczą w rozumieniu art. 2 ustawy z dnia 2 lipca 2004 r.

${ }^{34}$ Por. M. Sieradzka, Ustawa o przeciwdziataniu nieuczciwym praktykom rynkowym. Komentarz (Komentarz do art. 17 ustawy o przeciwdziałaniu nieuczciwym praktykom rynkowym), Warszawa 2008, Lex.

35 Ustawa o przeciwdziataniu nieuczciwym praktykom rynkowym, op. cit., art. 2 pkt 10.

36 Ustawa z dnia 2 lipca 2004 r. o swobodzie dziatalności gospodarczej, Dz. U. Nr 173, poz. 1807 ze $\mathrm{zm}$.

37 Por. art. 2 s.d.g.. 
o swobodzie działalności gospodarczej ${ }^{38}$. Przy założeniu takiej wykładni zorganizowanie systemu konsorcyjnego w ramach działalności spółdzielczej kasy oszczędnościowo-kredytowej nie podlegałoby karze.

Ustawodawca przewidział kwalifikowany typ przestępstwa zarządzania mieniem w systemie konsorcyjnym, o ile wartość zarządzanego mienia jest wielka. Do oceny wielkości mienia zastosowanie ma art. 115 §6 Kodeksu karnego ${ }^{39}$, w którym ustanowiono, że mieniem wielkiej wartości jest to, którego wartość w czasie popełnienia czynu zabronionego przekracza jeden milion złotych. Karze podlega także osoba działająca w imieniu lub - co interesujące - w interesie przedsiębiorcy prowadzącego działalność (gospodarczą) w systemie konsorcyjnym. Ściganie przestępstw następuje na wniosek pokrzywdzonego lub opisanych w ustawie podmiotów uprawnionych.

\section{ZAKOŃCZENIE}

Ustawodawca spełniając obowiązek implementacji prawa Unii Europejskiej do krajowego porządku prawnego, zadośćuczynił konstytucyjnej gwarancji ochrony przed nieuczciwymi praktykami rynkowymi. Sama realizacja powinności konstytucyjnej nie okazała się całościowa. Ustawa nie chroni innych podmiotów niż konsumenci. Jest to kolejna ustawa $\mathrm{z}$ zakresu regulacji dążących do ochrony konkurencji i konsumentów.

Nie wpływa pozytywnie na system prawny wprowadzanie oddzielnych, autonomicznych regulacji, odrębnych treściowo w odniesieniu do kolejnych ustaw. W ustawie nie przewidziano szczególnych (żadnych) kompetencji dla Prezesa UOKiK - organu, który dotychczas kumulował uprawnienia do podejmowania działań ochronnych w przypadku naruszenia interesów konsumentów albo konkurencji.

Można zgłaszać zastrzeżenia co do cywilnoprawnych form ochrony przewidzianych w ustawie. Umożliwienie skorzystania z form kompensacji majątkowej oraz niemajątkowej nie stanowi novum w systemie prawnym. Zezwolenie na wystąpienie ze środkiem ochrony przez konsumenta, jakkolwiek niekiedy entuzjastycznie przyjęte $\mathrm{w}$ piśmiennictwie, nie nadaje legitymacji procesowej potencjalnie najbardziej zainteresowanemu podmiotowi (Prezeso-

${ }^{38}$ Wyrok Wojewódzkiego Sądu Administracyjnego w Gdańsku z 4 kwietnia 2012 r., sygn. akt: I SA/Gd 1266/11, dostępny w Centralnej Bazie Orzeczeń Sądów Administracyjnych http:// orzeczenia.nsa.gov.pl.

39 Ustawa z dnia 6 czerwca 1997 r. Kodeks postępowania karnego, Dz. U. Nr 88, poz. 553 ze zm. 
wi UOKiK), oraz przedsiębiorcom, którzy mogą być bardziej zainteresowani walką z konkurencją stosującą nieuczciwe praktyki rynkowe niż konsumenci.

Uregulowania karnoprawne powodują, z jednej strony, wątpliwości natury konstytucyjnej wobec niedookreślonego katalogu zachowań stanowiących agresywne praktyki rynkowe - które to praktyki w konsekwencji stanowią wykroczenia. $Z$ drugiej strony karalność tworzenia systemów konsorcyjnych nie jest zupełna, a więc cel regulacji - wyeliminowanie takich systemów - może nie zostać spełniony.

Być może możliwe będzie rozpoczęcie dyskusji nad propozycjami ewentualnych zmian w opisywanej ustawie.

\section{BIBLIOGRAFIA}

Banasiński C., i Bychowska M., Ekonomiczne aspekty stosowania art. 15 ust. 1 pkt 4 ustawy o zwalczaniu nieuczciwej konkurencji, „Przegląd Prawa Handlowego”, 2011, nr 11.

Du Cane D., Nieuczciwa konkurencja a dobre obyczaje oraz class action po polsku, „Przegląd Prawa Handlowego", 2009, nr 3.

Grochowski M., Wadliwośc umów konsumenckich (w świetle przepisów o nieuczciwych praktykach rynkowych), „Państwo i Prawo”, 2009, nr 7.

Jurasz W., Zakres podmiotowy regulacji ustaw: o ochronie konkurencji i konsumentów, zwalczaniu nieuczciwej konkurencji oraz przeciwdziataniu nieuczciwym praktykom rynkowym. Konsument jako podmiot chroniony przed praktykami zakazanymi w tych ustawach, „Ochrona konkurencji i konsumentów w Polsce - wybrane zagadnienia Dodatek do Monitora Prawniczego 2010 nr 8", b.d.

Kopaczyńska-Pietrzak K., Czyn nieuczciwej konkurencji a nieuczciwa praktyka rynkowa, „Monitor Prawa Handlowego”, 2012, nr 3.

Michalak A., Przeciwdziatanie nieuczciwym praktykom rynkowym. Komentarz, C.H. Beck, Warszawa 2008, Legalis.

Namysłowska M., Nowa ustawa o przeciwdziataniu nieuczciwym praktykom rynkowym, „Monitor Prawniczy”, 2007, nr 23.

Raglewski J., Wybrane problemy interpretacyjne przepisów karnych ustawy o zwalczaniu nieucziwwej konkurencji z 1993 r., „Zeszyty Naukowe Uniwersytetu Jagiellońskiego. Prace z Prawa Własności Intelektualnej”, 2010, t.109, nr 3.

Sieradzka M., Naruszenie prawa do znaku towarowego użytego w meta-tags, „Monitor Prawniczy", 2008, nr 12.

Sieradzka M., Actio popularis jako instrument ocbrony interesów konsumentów przed nieuczciwymi praktykami rynkowymi, „Przegląd Prawa Handlowego”, 2008, nr 3.

Ustawa o przeciwdziataniu nieucziwym praktykom rynkowym. Komentarz. (Komentarz do art.17 ustawy o przeciwdziałaniu nieuczciwym praktykom rynkowym), Warszawa 2008, Lex. 
Stefanicki R., Ustawa o przeciwdziataniu nieucziwym praktykom rynkowym. Komentarz, LexisNexis, Warszawa 2009, LexPolonic.Szwaja, Janusz, Tischner A., Implementacja dyrektywy 2005/29/WE o zwalczaniu nieuczciwych praktyk handlowych do prawa polskiego, „Monitor Prawniczy”, 2007, nr 20.

Zientara A., Ostatnie zmiany ustawy o zwalczaniu nieuczciwej konkurencji, „Monitor Prawniczy", 2001, nr 6.

Wyrok Sądu Ochrony Konkurencji i Konsumentów z dnia 23 lutego 2006 r., XVII Ama $118 / 04$.

Wyrok Sadu Ochrony Konkurencji i Konsumentów z dnia 25 marca 2010 r., XVII Ama 43/2009.

Wyrok Wojewódzkiego Sądu Administracyjnego w Gdańsku z 4 kwietnia 2012 r., sygn. akt: I SA/Gd 1266/11. 